\title{
ECONOMIC ACTIVITY AND REPRODUCTIVE BEHAVIOURS IN POLAND*
}

\section{Abstract}

Poland is a country with one of the lowest fertility rates in Europe. Many researchers have attempted to explain the reasons for this state of affairs. In the literature, the situation on the labour market is considered to be one of the determinants of low fertility - difficulty in finding work, job insecurity, and the high expectations of employers vis-a-vis employees. Young people often postpone their decision to become parents in order to receive a better education, find a job, and establish their position on the labour market. Studies on the impact of economic activity on reproductive behaviours have produced ambiguous results, depending on the country. Differentiation is related to the situation on the labour market (employment, wages), institutional support, and the division of roles within the family. In countries with high wages (e.g. Denmark), the unemployment of one parent does not have to limit fertility. In countries with relatively low-wages, the effects of unemployment may contribute to the postponement of parenthood (e.g. Spain). The aim of this paper is to examine the impact of the economic activity of both partners on the chance of having a first child in Poland. The analysis covers the socio-economic characteristics of both partners, such as place of residence, type of relationship, type of household, woman's age, partner's education level, and religiosity. The following hypotheses are tested: (1) the employment of both partners increases the chance of having a first child; and (2) the unemployment of one of the partners decreases the chance of having a first child. To verify these hypotheses, the random effect logit model was used. The data originate from the Social Diagnosis 2003-2013.

Keywords: fertility, reproductive behaviours, economic activity, panel data models, random effect logit models.

JEL Classification: J10, J12, J13, C23.

Marta Szklarska, Cracow University of Economics, Faculty of Finance and Law, Department of Mathematics, Rakowicka 27, 31-510 Kraków, Poland, e-mail: marta.szklarska@uek.krakow.pl, ORCID: https://orcid.org/0000-0003-0297-4389.

* This publication presents the results of research project financed from funds granted to the Faculty of Finance and Law at the Cracow University of Economics within the framework of the subsidy for the maintenance of research potential. 


\section{Introduction}

The transformation of reproductive behaviours in Poland shares the general tendencies observed in other European countries. Typical features of the changes in progress include: postponing first births, subsequently leading to the postponing or even lack of further children, postponing births in connection with education, the increasing percentage of cohabitations and LAT relationships (living apart together) as well as the increasing frequency of extramarital births. A particularly disturbing phenomenon is the decreasing level of fertility. Currently, Poland is one of the countries with a fertility rate determined as the lowest among the low (the total fertility rate is 1.3). The long-term maintenance of fertility at such a low level risks entering the so-called the low-fertility trap (Lutz \& Skirbekk 2005, Lutz, Skirbekk \& Testa 2006), as the changes in the age structure of the population caused by this phenomenon can consequently lead to a situation where the increase in the total fertility rate up to 1.5 becomes very difficult or even impossible.

Demographers tend to consider the observed phenomena within the Second Demographic Transition theory formulated by Lesthaeghe (1991, 2010) and van de Kaa (1987, 1997, 1999). In Poland, the symptoms of the Second Demographic Transition appeared together with the systemic transformation of the 1990s (Lesthaeghe and Surkyn 2004, Speder and Kapitany 2009, Frejka 2008, Kotowska et al. 2008, Sobotka 2008). Initially, demographers were rather sceptical about explaining the changes taking place within the Second Demographic Transition, arguing that they resulted mainly from the limitations in daily life that emerged in the wake of the transformation. Over time, however, they began to admit the influence of the combination of determinants of the Second Demographic Transition (see Lesthaeghe and Surkyn 2004). Kotowska and others (2008) claim that the development of post-industrial society in Poland is similar to that taking place in West European countries. What they emphasize, however, is that the main influence on the phenomena in question is the structural ingredient of modernization, which accentuates the significance of economic limitations (see Kurkiewicz 1998). Therefore, of crucial importance are the situation on the labour market, difficulties in combining professional life with family responsibilities, and the high costs of supporting children (see Nowe wzorce... 2014). Young people postpone their decision to start a family in favour of gaining employment and establishing their position on the labour market. Additionally, insufficiently developed institutional 
support is another factor which undermines the reconciliation of work with family responsibilities.

Fertility decline is also considered in the context of the New Home Economics formulated by Becker $(1960,1981,1990)$. Becker points to the influence of two factors in explaining the transformation of reproductive behaviour - the income effect and the price effect. The income effect means that with the increase of family income (usually associated with a higher level of education) one should expect an increase in demand for children who, according to Becker's theory, are treated as goods. In fact, the decline in fertility coincided with an increase in income. Becker put this phenomenon down to the "quality" of the child, which depends directly on the spending incurred on his upbringing and education. Hence, higher-income families tend to rather increase the quality of children than to increase their number. The price effect is associated with the opportunity costs of childbearing. These costs are understood as any lost benefits resulting from reproductive decisions. The time that an individual could devote to his or her personal development and paid work is invested in the family. Therefore, people with higher incomes lose more than people with lower incomes. Becker's theory has been formulated for the traditional division of roles within a family the man provides financial support, while the woman takes care of the house and brings up the children. The increased activity of women on the labour market leads to a conflict between professional and family roles. This conflict can be further exacerbated by insufficient institutional support. Hence, the income effect primarily concerns men, while the price effect mainly concerns women. In the situation where both partners share their family duties, the income effect can also relate to women.

Research on the influence of economic activity on reproductive behaviour was conducted for several European countries. Vignoli, Drefahl and De Santis (2012) analysed Italian couples and showed that the chance of having a first child was higher for couples where both partners had a permanent employment contract than for couples where one of the partners had a temporary contract. E. Santarelli (2011) found that the risk of having a first child was higher in the case of Italian couples with a single breadwinner than in the case of couples where both partners worked. Baizán (2005) showed that couples' behaviour could vary. In the UK and Italy, the chance of having a second child was higher if the man had a permanent job and the woman was inactive (the single breadwinner model) in comparison to couples where both partners had a permanent employment contract (the dual-earner model). In Denmark, however, the chance was higher if 
both partners worked. The observed differences are related to, for instance, the different situation on the labour market (employment levels, wages), different institutional support, and cultural determinants.

Research on the relationship between economic activity and fertility in Poland is conducted mainly in the context of female economic activity (see Strukturalne... 2009, Matysiak 2009, 2011, Matysiak \& Vignoli 2010). The resulting conclusion is that women's employment has no influence on the first birth, but it has a negative impact on second births (Matysiak 2009, 2011, Matysiak \& Vignoli 2010). An approach which takes into account the qualities of both partners is not common (see, e.g., Soja 2005, Mynarska 2011, Nowe wzorce... 2014). Such an approach is justified as reproductive decisions are made by both partners and it expands knowledge about the conditions of contemporary reproductive behaviours in Poland. According to the research conducted by Mynarska (2011), having a job and a stable position on the labour market are the key factors in the process of making reproductive decisions.

The aim of this paper is to examine how the economic activity of both partners in Poland affects the chance of having a first child. In addition, a secondary aim was set - to identify the factors conducive to the increase in childless families. Therefore, the analysis takes into account the socio-economic qualities of couples, such as place of residence, type of relationship, type of household, woman's age, partners' education level, and religiosity. Taking into consideration the results of previous research, the following hypotheses have been tested: (1) the employment of both partners increases the chance of having a first child; (2) the unemployment of one of the partners decreases the chance of having a first child. To verify these hypotheses, the random effect logit model was used. The data originate from the Social Diagnosis 2003-2013.

\section{Description of Data and Variables}

The analysis of the influence of couples' economic activity on the chance of having a first child was conducted on the basis of data derived from Social Diagnosis ${ }^{1}$. All the information contained there is of a panel character and refers to numerous aspects of the way households function and the lives of their members. The analysis included couples that participated in at least two rounds of the research. The procedure was as follows: among the childless couples who took part in the research conducted in 2003, those in which the

I $\quad{ }^{1}$ Date of data download: 23.03.2014. 
woman was of reproductive age (15 to 49 years) were selected. Then it was determined whether in the next round of the study (2005) a child was born or not. The couples that participated in the surveys conducted in 2005, 2007, 2009, and 2011 were selected in the same way ${ }^{2}$.

Table 1 presents the characteristics of the analysed population structure according to the variables applied in the research.

Considering the aim of this paper, the main explanatory variable was the economic activity of partners. Four models of couples' economic activity were constructed (variable: economic model of family): in the first model, both partners are employed; in the second model, the man is employed and the woman is unemployed; in the third model, the man is unemployed and the woman is employed; and in the fourth model, both partners are unemployed. During the period under consideration, relationships in which both partners were working dominated among childless couples. Depending on the round of research, they constituted $65-74 \%$ of all childless couples (see Table 1). The profile with the man as the breadwinner of the family accounted for $15-21 \%$ of childless couples. The smallest group consisted of couples in which neither partner was employed (less than $10 \%$ of couples).

Additionally, the analysis takes into account control variables which, due to the examined phenomenon (the chance of having a first child), are of major importance. These are: education level, place of residence, type of household, type of relationship, religiosity, and woman's age.

The education level variable was divided into three levels: primary (basic, lower secondary, basic vocational), secondary (secondary, secondary vocational, post-secondary), and higher. This variable was determined on the basis of information on the level of education completed at the time of the research. In the population structure of the analysed couples according to partner education level, the following regularities deserve attention: an increase in the level of education of women was observed. This reflects the increase in the share of couples in which the woman had higher education. In 2003, such couples accounted for 36\%, and in $2011-47 \%$. On the other hand, the share of relationships in which the woman had secondary or basic

\footnotetext{
${ }^{2}$ Determining the actual number of children was only possible for the couples who participated in the 2011 study. Hence, for couples who did not participate in this round of the research, a potential error might have been introduced regarding the actual number of children they have. This situation also occurred in a study carried out by Vignoli, Drefahl and Santis (2012). However, the researchers noticed that they were analysing women at a relatively young age (16-49 years), the mortality of newborns and children was very low, parenting and leaving the family home were deferred, and hence the potential error was probably irrelevant (see Vignoli, Drefahl \& Santis (2012, pp. 49). A similar approach is therefore adopted in the paper.
} 
Table 1. Structure of Childless Couples

\begin{tabular}{|c|c|c|c|c|c|}
\hline Variable & \multicolumn{5}{|c|}{ Structure of childless couples $(\%)$} \\
\hline The panel round & 2003 & 2005 & 2007 & 2009 & 2011 \\
\hline $\begin{array}{l}\text { Economic model of family } \\
\text { both partners are employed } \\
\text { man is employed and woman is not employed } \\
\text { man is not employed and woman is employed } \\
\text { neither partner is employed }\end{array}$ & $\begin{array}{c}65.7 \\
15.7 \\
10.8 \\
7.8\end{array}$ & $\begin{array}{c}64.7 \\
19.1 \\
11.8 \\
4.4\end{array}$ & $\begin{array}{r}72.3 \\
20.5 \\
2.7 \\
4.5\end{array}$ & $\begin{array}{c}67.5 \\
18.8 \\
10.7 \\
3\end{array}$ & $\begin{array}{c}74.4 \\
15.4 \\
6.2 \\
4\end{array}$ \\
\hline $\begin{array}{l}\text { Woman's education level } \\
\text { primary } \\
\text { secondary } \\
\text { higher }\end{array}$ & $\begin{array}{l}22.5 \\
41.2 \\
36.3\end{array}$ & $\begin{array}{l}19.1 \\
48.5 \\
32.4\end{array}$ & $\begin{array}{l}27.7 \\
32.1 \\
40.2\end{array}$ & $\begin{array}{l}17.5 \\
37.6 \\
44.9\end{array}$ & $\begin{array}{c}18 \\
35.2 \\
46.7\end{array}$ \\
\hline $\begin{array}{l}\text { Man's education level } \\
\text { primary } \\
\text { secondary } \\
\text { higher }\end{array}$ & $\begin{array}{l}43.2 \\
28.4 \\
28.4\end{array}$ & $\begin{array}{c}42.6 \\
32.4 \\
25\end{array}$ & $\begin{array}{c}39.3 \\
33 \\
27.7\end{array}$ & $\begin{array}{c}36.8 \\
35 \\
28.2\end{array}$ & $\begin{array}{l}32.2 \\
33.9 \\
33.9\end{array}$ \\
\hline $\begin{array}{l}\text { Place of residence } \\
\text { urban } \\
\text { rural }\end{array}$ & $\begin{array}{l}65.7 \\
34.3\end{array}$ & $\begin{array}{l}63.2 \\
36.8\end{array}$ & $\begin{array}{l}61.6 \\
38.4\end{array}$ & $\begin{array}{l}64.1 \\
35.9\end{array}$ & $\begin{array}{l}59 \\
41\end{array}$ \\
\hline $\begin{array}{l}\text { Type of household } \\
\text { single-family } \\
\text { multifamily }\end{array}$ & $\begin{array}{l}53.9 \\
46.1\end{array}$ & $\begin{array}{l}55.9 \\
44.1\end{array}$ & $\begin{array}{l}54.5 \\
45.5\end{array}$ & $\begin{array}{l}66.7 \\
33.3\end{array}$ & $\begin{array}{l}60.8 \\
39.2\end{array}$ \\
\hline $\begin{array}{l}\text { Type of relationship } \\
\text { marriage } \\
\text { cohabitation }\end{array}$ & $\begin{array}{c}96.1 \\
3.9\end{array}$ & $\begin{array}{l}89.7 \\
10.3\end{array}$ & $\begin{array}{l}83.9 \\
16.1\end{array}$ & $\begin{array}{l}81.6 \\
18.4\end{array}$ & $\begin{array}{l}79.3 \\
20.7\end{array}$ \\
\hline $\begin{array}{l}\text { Woman's religiosity } \\
\text { religious } \\
\text { averagely religious } \\
\text { irreligious } \\
\text { undisclosed }\end{array}$ & $\begin{array}{c}48 \\
16.7 \\
28.4 \\
6.9\end{array}$ & $\begin{array}{l}44.1 \\
16.2 \\
27.9 \\
11.8\end{array}$ & $\begin{array}{c}48.2 \\
21.4 \\
25 \\
5.4\end{array}$ & $\begin{array}{c}35.9 \\
26.1 \\
30.8 \\
7.2\end{array}$ & $\begin{array}{c}34.8 \\
24.2 \\
34.8 \\
6.2\end{array}$ \\
\hline $\begin{array}{l}\text { Man's religiosity } \\
\text { religious } \\
\text { averagely religious } \\
\text { irreligious } \\
\text { undisclosed }\end{array}$ & $\begin{array}{c}36.3 \\
24.5 \\
33.3 \\
5.9\end{array}$ & $\begin{array}{l}29.4 \\
22.1 \\
32.4 \\
16.1\end{array}$ & $\begin{array}{l}34.8 \\
28.6 \\
25.9 \\
10.7\end{array}$ & $\begin{array}{c}30.8 \\
26.1 \\
34.1 \\
9\end{array}$ & $\begin{array}{c}24.7 \\
26 \\
33.9 \\
15.4\end{array}$ \\
\hline
\end{tabular}


Table 1 cnt'd

\begin{tabular}{l|c|c|c|c|c}
\hline \multicolumn{1}{c|}{ Variable } & \multicolumn{4}{|c}{ Structure of childless couples (\%) } \\
\hline The panel round & 2003 & 2005 & 2007 & 2009 & 2011 \\
\hline Woman's age & & & & & \\
$15-24$ & 20.6 & 14.7 & 13.4 & 15.8 & 10.6 \\
$25-29$ & 41.2 & 38.2 & 34.8 & 35 & 37.4 \\
$30-34$ & 6.9 & 16.2 & 23.2 & 25.6 & 23.8 \\
$35-39$ & 7.8 & 11.8 & 10.7 & 8.1 & 12.8 \\
$40-44$ & 8.8 & 7.3 & 3.6 & 7.4 & 10.1 \\
$45-49$ & 14.7 & 11.8 & 14.3 & 8.1 & 5.3 \\
$N$ & 102 & 68 & 112 & 234 & 227 \\
\hline
\end{tabular}

Source: author's own elaboration.

education decreased. Until 2005, couples in which the woman had secondary education, and since 2007, couples in which the woman had a university degree, were dominant. Taking into account the man's level of education, an increase in the percentage of childless couples in which the man had secondary or higher education was observed, with a simultaneous decline in the share of couples in which the man had primary education (from $43 \%$ in 2003 to $32 \%$ in 2011). Except for the last panel (2011), couples in which the man had basic education were dominant.

For the place of residence variable, two levels were distinguished: rural and urban areas. Most of the childless couples lived in towns and cities, but their share decreased from $66 \%$ in 2003 to $59 \%$ in 2011.

The type of household variable was divided into two levels: the single-family household and the multifamily household. In the period under consideration, childless couples living in single-family households were dominant. They constituted from $54 \%$ to $67 \%$, depending on the survey round.

For the type of relationship variable, two states were distinguished: marriage and cohabitation. There was a significant increase in the share of childless couples cohabiting. In the second round of the research, they constituted $4 \%$ of couples, while by 2011 this figure had risen to $21 \%$. Nevertheless, marriage was still the dominant type of relationship.

The religiosity variable was divided into four groups: religious, averagely religious, irreligious, and undisclosed. When analysing the structure of childless couples with respect to the religiosity of partners, attention was paid to the decline in the share of couples in which both the man and the 
woman were religious in favour of an increasing share of couples in which partners were averagely religious or irreligious. In the male population, the scope of change was greater.

Let us now turn to the structure of couples in relation to the woman's age in childless couples. In the period under consideration, the largest group were couples in which the woman was aged from 25 to 29 years. Their share, however, gradually decreased from $41 \%$ in 2003 to $37 \%$ in 2011. A decrease in the share was also recorded in two extreme age groups, i.e. in the youngest, aged 15-24 years, and in the oldest, aged 44-49 years. On the other hand, the share of couples in which the woman was aged 30-34 or 35-39 years increased.

The use of panel data made it possible to analyse the dynamics of processes. Therefore, a time variable (year) was introduced, indicating the time at which individual research rounds were conducted $(2003,2005,2007$, 2009, and 2011).

\section{Model}

The birth of a child is an event to which two states can be ascribed - it either occurred or it did not. Hence, we are dealing with a binary variable, for the modelling of which a special class of models is used. In the literature on the subject, various specifications can be found for the binomial variable model (see, e.g. Baltagi 2005, Mikroekonometria... 2012, Maddala 2006). In the presented case, the latent variable $y_{i}^{*}(i=1,2, \ldots, n)$ is used, which reflects the tendency or ability of an individual to make a decision $y_{i}$. If the tendency $y_{i}^{*}$ is positive, we observe $y_{i}=1$, and in other cases we observe $y_{i}=0$, which is written as:

$$
y_{i}=\left\{\begin{array}{l}
1, \text { if } y_{i}^{*}>0 \\
0, \text { if } y_{i}^{*} \leq 0
\end{array} .\right.
$$

It is assumed that the latent variable $y_{i}^{*}$, which is the object of modelling, is a function of explanatory variables:

$$
y_{i}^{*}=x_{i} \beta+u_{i},
$$

where $x_{i}=\left(1, x_{1 i}, x_{2 i}, \ldots, x_{k i}\right)$ is a covariate vector, $\beta=\left(\beta_{0}, \beta_{1}, \beta_{2}, \ldots, \beta_{k}\right)^{T}$ is a vector of parameters and $u_{i}$ is the error distributed by the standard logistic distribution which leads to the logit model or distributed by the standard normal distribution which leads to the probit model. As in the empirical part 
of the paper, a logit model was used. From this moment we assume that that error term has the standard logistic distribution.

Marginal effects can be used to interpret the results ${ }^{3}$. They are equal for the logit model:

$$
\frac{\partial p_{i}}{\partial x_{j i}}=\beta_{j} \frac{\exp \left(x_{i} \beta\right)}{\left[1+\exp \left(x_{i} \beta\right)\right]^{2}}=\beta_{j} p_{i}\left(1-p_{i}\right),
$$

where $p_{i}=\frac{\exp \left(x_{i} \beta\right)}{1+\exp \left(x_{i} \beta\right)}$ is the probability of taking the value 1 by the explained variable.

Because $p_{i}\left(1-p_{i}\right)>0$ a sign of $\beta_{j}$ shows the direction of the influence of variable $x_{j i}$ on the explained variable as follows:

- if $\beta_{j}>0$ then, if $x_{j i}$ increases by (one) unit, then the probability that the explained variable will take the value 1 increases;

- if $\beta_{j}<0$ then, if $x_{j i}$ increases by (one) unit, then the probability that the explained variable will take the value 1 decreases.

The specification (1), (2) is used to define the model for panel data. This is done by introducing the individual effects $\alpha_{i}$ into the model and adding the second dimension $t$. Therefore, the binominal variable model for panel data is written as (see, e.g., Mikroekonometria... 2012):

$$
\begin{aligned}
& y_{i t}^{*}=x_{i t} \beta+\alpha_{i}+u_{i t} \\
& y_{i t}=\left\{\begin{array}{l}
1, \text { if } y_{i t}^{*}>0 \\
0, \text { if } y_{i t}^{*} \leq 0
\end{array},\right.
\end{aligned}
$$

where:

$i=1,2, \ldots, N-$ individual dimension,

$t=1,2, \ldots, T$ - time dimension,

$y_{i t}^{*}-$ latent variable,

$y_{i t}-$ dependent variable,

$x_{i t}$ - covariate vector,

$u_{i t}$ - error term,

$\beta$ - vector of parameters.

Treating individual effects $\alpha_{i}$ as fixed (assuming that objects differ and these differences are constant over time and are not accidental) leads to the fixed effects logit model, while treating them as random variables gives the

I $\quad{ }^{3}$ The odds ratio can also be used (see, e.g., Mikroekonometria ... 2012). 
random effects logit model. The conditional maximum likelihood is used to estimate parameters of the fixed effects logit model, whereas to estimate parameters of the random effects logit model the maximum likelihood is used. The necessity of applying the conditional maximum likelihood causes the fixed effects logit model to have some disadvantages. Firstly, the conditional likelihood function, with any number of periods $(T>1)$, creates a product of conditional likelihood functions only of those individuals for which the value of the dependent variable has changed at least once. Secondly, explanatory variables constant over time are not included. Moreover, it is not possible to estimate individual effects. Therefore, it is not possible to calculate the probability of taking the value 1 or 0 by the explained variable. The random effects logit model does not have such limitations, but a strong assumption of independence of individual effects from explanatory variables should be made ${ }^{4}$. The disadvantages of the fixed effects logit model meant that it was not used in the empirical part of this paper.

\section{Results}

When constructing the models, various sets of explanatory variables were taken into account. The final set of explanatory variables was determined by the substantives considerations and the Akaike information criterion (AIC).

The obtained results indicate that couples in which the man is the breadwinner are less likely to give birth to a first child when compared with couples in which both partners work. When analysing the relationship between economic activity and fertility, A. Matysiak (2009) formulated the view that women are characterized by an unobserved tendency to have a job before the birth of a child. What is striking is the result obtained for couples in which the woman is the breadwinner (the man is unemployed, the woman is employed) and for couples in which neither partner works. The probability of having a child for such couples does not differ statistically significantly from the probability for couples in which both partners work. In terms of economic conditions, one could assume that such couples treat the lack of work as a temporary state or can rely on some kind of external support. Other explanations (e.g. having a child to satisfy parental feelings) require additional research.

\footnotetext{
${ }^{4}$ More about the models can be found in e.g. Baltagi (2005) and Mikroekonometria... (2012).
} 
Table 2. Estimation Results

\begin{tabular}{|c|c|c|c|}
\hline \multirow[b]{2}{*}{ Variable } & \multicolumn{3}{|c|}{ The random effects logit model } \\
\hline & estimate & $p$-value & $\begin{array}{l}\text { standard } \\
\text { error }\end{array}$ \\
\hline $\begin{array}{l}\text { Economic model of family } \\
\text { both partners are employed (ref.) } \\
\text { man is employed and woman is not employed } \\
\text { man is not employed and woman is employed } \\
\text { neither partner is employed }\end{array}$ & $\begin{array}{c}-0.684^{* *} \\
-0.075 \\
-0.211\end{array}$ & $\begin{array}{l}0.018 \\
0.841 \\
0.671\end{array}$ & $\begin{array}{l}0.289 \\
0.375 \\
0.497\end{array}$ \\
\hline $\begin{array}{l}\text { Place of residence } \\
\text { rural (ref.) } \\
\text { urban }\end{array}$ & -0.013 & 0.956 & 0.231 \\
\hline $\begin{array}{l}\text { Type of household } \\
\text { single-family (ref.) } \\
\text { multifamily }\end{array}$ & $0.460^{*}$ & 0.055 & 0.240 \\
\hline $\begin{array}{l}\text { Type of relationship } \\
\text { marriage (ref.) } \\
\text { cohabitation }\end{array}$ & $-1.579 * * *$ & 0.000 & 0.372 \\
\hline $\begin{array}{l}\text { Man's religiosity } \\
\text { religious (ref.) } \\
\text { averagely religious } \\
\text { irreligious } \\
\text { undisclosed } \\
\end{array}$ & $\begin{array}{l}-0.327 \\
-0.297 \\
-0.143 \\
\end{array}$ & $\begin{array}{l}0.191 \\
0.239 \\
0.651\end{array}$ & $\begin{array}{l}0.250 \\
0.252 \\
0.317\end{array}$ \\
\hline Woman's age & $-0.135^{* * *}$ & 0.000 & 0.023 \\
\hline $\begin{array}{l}\text { Woman's education level } \\
\text { primary (ref.) } \\
\text { secondary } \\
\text { higher } \\
\end{array}$ & $\begin{array}{c}0.345 \\
0.793^{* *}\end{array}$ & $\begin{array}{l}0.251 \\
0.013 \\
\end{array}$ & $\begin{array}{l}0.301 \\
0.321\end{array}$ \\
\hline $\begin{array}{l}\text { Year } \\
2003 \text { (ref.) } \\
2005 \\
2007 \\
2009 \\
2011\end{array}$ & $\begin{array}{c}0.584 \\
0.844^{* *} \\
1.192^{* * *} \\
0.823^{* *}\end{array}$ & $\begin{array}{l}0.191 \\
0.028 \\
0.001 \\
0.027\end{array}$ & $\begin{array}{l}0.446 \\
0.384 \\
0.359 \\
0.372\end{array}$ \\
\hline $\ln L$ & & -367.036 & \\
\hline Rho & & 0.014 & \\
\hline$A I C$ & & 766.072 & \\
\hline$N$ & & 743 & \\
\hline
\end{tabular}

Notes: $p<0.1 ;{ }^{* *} p<0.05 ;{ }^{* * *} p<0.01$.

Source: author's own elaboration. 
Taking into account the place of residence variable, the probability of having a first child for couples living in rural areas is not statistically different from the probability of having a first child for couples living in urban areas. This means that place of residence (urban or rural) does not differentiate the reproductive behaviours of childless couples, although in older generations such a differentiation did occur, as evidenced by the results of the analysis conducted by B. Osiewalska $(2015)^{5}$, who showed that couples living in rural areas were less likely to remain childless than couples living in urban areas.

The probability of having a first child for couples living in multifamily households is higher compared to couples living in single-family households. It can be assumed that couples in multifamily households that can rely on direct help from other family members are more likely to decide on having a first child.

In the case of the type of relationship variable (marriage, cohabitation), the results showed that the probability of the birth of a first child was lower for cohabiting couples than for married couples. This shows that for childless couples it is important that prior to the birth of a first child their relationship is formal (marital). M. Mynarska and M. Styrc (2014) obtained the same result for childless women intending to have a first child.

In light of the obtained results, it turns out that male religiosity does not differentiate the reproductive behaviours of childless couples. The formation of families in the context of religiosity was considered by, among others, M. Mynarska and M. Styrc (2014). The results they obtained indicate that religiosity is important at the stage of planning parenthood. Its significance changes when it comes to realizing reproductive plans.

The probability of having a first child is significantly related to a woman's age. Some negative connections have been observed - the probability of the birth of a first child decreases with age.

The estimated model indicates that in couples in which the woman has higher education, the probability of having a first child is higher compared to couples in which the woman has primary education. The explanation for this can be formulated in the context of economic conditions. A higher level of education is often associated with better career prospects and these, in turn, may justify the expectation of higher income. According to Becker's theory, an increase in income contributes to an increase in the demand for children, and therefore the obtained results can be interpreted as revealing the income effect. M. Mynarska and M. Styrc (2014) came to similar

${ }^{5}$ The analysis covered the couples in which a woman at the time of the research, i.e. in 2011, was at least 40 years old. 
conclusions as regards the connections between education and the intention of having a first child.

The reproductive behaviours of couples can be considered in the context of conditions that occurred in a given calendar period. This approach was made possible by the introduction of the year variable into the model. It turned out to be statistically significant. The exception in this respect was the year 2005. Compared to the year 2003, the probability of having a first child was higher in 2007, 2009, and 2011. The conditions that existed in those years had a positive effect on the likelihood of expanding a childless family.

\section{Conclusions}

The aim of the research was to investigate how the economic activity of partners affects the probability of having a first child. In addition, the goal of the paper was to identify the factors conducive to the execution of the reproductive plans of childless couples. The results obtained allow the following general conclusions to be made:

1. The reproductive behaviours of the analysed couples are varied,

2. This diversity is mainly connected with cultural conditions. In the model, these were expressed by the following variables: place of residence (rural or urban areas), type of household (single- or multifamily), type of relationship (marriage or cohabitation) and religiosity,

3. The economic activity profiles of partners were found to have a significant impact on the expansion of families.

Among the more detailed arrangements for first-order births, the following statements deserve attention:

1. Childless couples in which both partners are employed have a higher chance of a first child than couples in which the man is the breadwinner. When attempting to explain these results, the situation of childless families should be considered. According to research carried out by M. Mynarska and M. Styrc (2014), when planning a first child it is important to achieve a stable financial position. This stability mainly consists of both partners having a job and owning a flat. Having achieved a good standard of living, which gives them a sense of material stability, the couple decide to have their first child. Therefore, both partners being employed is a determinant of first-order births.

2. The place of residence (rural or urban) does not differentiate the reproductive behaviours of childless couples. Having at least one child is desirable for the vast majority of families regardless of where they live. 
Similar results regarding older generations (1942-1966) were obtained by E. Soja (2005).

3. The type of relationship significantly differentiates the reproductive behaviour of childless couples. Cohabiting couples are less likely to have a first child compared to couples in formal relationships. This suggests that for childless couples it is important that prior to the birth of a first child they live in a marital relationship. This conclusion is supported by the results of research conducted by M. Mynarska and M. Styrc (2014). The type of relationship is important already at the stage when childless couples are planning parenthood.

4. Living in a multifamily household is conducive to extending a childless family. This is perhaps connected with the lack of experience in caring for and raising a child, with the possibility of benefiting directly from the assistance of other household members who have a child, and also with insufficient institutional support.

5. The insignificant impact of a man's religiosity supports the view expressed above that having at least one child is desirable for the vast majority of families. The structure of couples according to religiosity shows that both partners have a similar level of religiosity. Thus, one can assume that the religiosity of one of partners reflects the religiosity of the family.

6. The higher a woman's level of education, the more positively it affects the chance of having a first child. This result can be explained in reference to Becker's economic theory of households. The higher the level of education, the higher the potential earnings. Thus, the impact of the income effect was revealed.

7. The conditions that were present in 2007,2009 , and 2011, in comparison to 2003 , favoured the extension of childless families. In the period under consideration, there were changes in the economic sphere that had an impact on the creation and development of families in Poland. Most important in this respect is the situation on the labour market. The analysed years saw a rise in the employment rate and decrease in the unemployment rate.

Summing up, it should be stated that there are no grounds to reject the hypotheses that the employment of both partners increases the chance of having a child and the unemployment of one of the partners reduces that chance. The probability of having a first child is lower for couples in which the man is the breadwinner compared to couples in which both partners work.

The above-mentioned findings on the reproductive behaviours of childless couples with different socio-demographic characteristics enrich our knowledge of the unrecognized conditions underlying the formation of 
families in Poland. In addition, they can help formulate recommendations for social policy as regards the creation of conditions on the labour market that would facilitate the reconciliation of work and family responsibilities. The conducted analysis can be the basis for further research on reproductive behaviours, with particular emphasis on the determinants conditioning the formation and extension of families in Poland.

\section{Bibliography}

Baizán, P. (2005) “Couples' Career and Fertility. An Event History Analysis of the ECHP Samples of Denmark, Italy, Spain and United Kingdom". Paper presented at the XXV International Population Conference, Tours, France, July 18-23, 2005, http:// iussp2005.princeton.edu/papers/51001.

Baltagi, B. H. (2005) "Econometric Analysis of Panel Data". Third edition. Chichester: John Wiley \& Sons.

Becker, G. S. (1960) "An Economic Analysis of Fertility" in G. B. Roberts (ed.) Demographic and Economic Change in Developed Countries, Universities-National Bureau Committee for Economic Research Conference Series 11. Princeton: Princeton University Press, pp. 209-40.

Becker, G. S. (1976) The Economic Approach to Human Behavior. Chicago: University of Chicago.

Becker, G. S. (1981) A Treatise on the Family. Cambridge: Harvard University Press.

Becker, G. S. (1990) Ekonomiczna teoria zachowań ludzkich [The economic approach to human behaviour]. Warszawa: PWN.

Frejka, T. (2008) "Overview Chapter 5: Determinants of Family Formation and Childbearing during the Societal Transition in Central and Eastern Europe". Demographic Research 19(7): 139-70, https://www.demographic-research.org/ volumes/vol19/7/19-7.pdf.

Kotowska, I., Jóźwiak, J., Matysiak, A. and Baranowska, A. (2008) "Poland: Fertility Decline as a Response to Profound Societal and Labour Market Changes?". Demographic Research 19(22): 795-854, https://www.demographic-research.org/ volumes/vol19/22/19-22.pdf.

Kurkiewicz, J. (1998) Modele przemian ptodności w wybranych krajach europejskich $w$ świetle drugiego przejścia demograficznego [Models of Fertility Changes in Selected European Countries in the Light of the Second Demographic Transition]. Zeszyty Naukowe. Seria specjalna: Monografie 131. Kraków: Wydawnictwo Akademii Ekonomicznej w Krakowie.

Kurowska, A. and Słotwińska-Rosłanowska, E. (2013) „Zatrudnienie a pierwsze i drugie urodzenia wśród kobiet w Polsce" [The role of employment status for first and second childbirths of women in Poland]. Studia Demograficzne 1(163): 37-51.

Lesthaeghe, R. (1991) The Second Demographic Transition in Western Countries: An Interpretation. IPD Working Paper 12. Brussels: Interuniversity Programme in Demography, https://pl.scribd.com/document/251019867/The-Second-DemographicTransition-in-Western-Countries-and-Interpretation-by-R-Lesthaeghe-1991-1992. 
Lesthaeghe, R. (2010) “The Unfolding Story of the Second Demographic Transition”. Population and Development Review 36(2): 211-51, https://deepblue.lib.umich.edu/ bitstream/handle/2027.42/79230/j.1728-4457.2010.00328.x.pdf?sequence $=1$.

Lesthaeghe, R. and Surkyn, J. (2004) "When History Moves on: The Foundations and Diffusion of a Second Demographic Transition”. Seminar on Ideational Perspectives on International Family Change. Ann Arbor: Population Studies Center, Institute for Social Research (ISR), University of Michigan, https://sdt.psc.isr.umich.edu/pubs/ online/WhenHistoryMovesOn_final.pdf.

Lutz, W. and Skirbekk, V. (2005) "Policies Addressing the Tempo Effect in Low-fertility Countries". Population and Development Review 31 (4): 669-720, https://doi. org/10.1111/j.1728-4457.2005.00094.x.

Lutz, W., Skirbekk, V. and Testa, M. R. (2006) "The Low-fertility Trap Hypothesis: Forces that May Lead to Further Postponement and Fewer Births in Europe". Vienna Yearbook of Population Research 2006(4): 167-92, http://www.austriaca. at/0xc1aa500d 0x00144e25.

Maddala, G. S. (2006) Ekonometria. Warszawa: Wydawnictwo Naukowe PWN.

Matysiak, A. (2009) "Employment First, Then Childbearing: Women's Strategy in Post-socialist Poland". Population Studies 63(3): 253-76, https://doi. org/10.1080/00324720903151100.

Matysiak, A. (2011) Interdependencies between Fertility and Women's Labour Supply. Dordrecht: Springer, https://link.springer.com/content/pdf/bfm\%3A978-94-007-1284$3 \% 2 \mathrm{~F} 1 . p d f$.

Matysiak, A. and Vignoli, D. (2010) Employment around the First Birth in Two Adverse Institutional Settings: Evidence from Italy and Poland. SPaDE Working Paper 2010/3. Stockholm: Stockholm University, Linnaeus Center on Social Policy and Family Dynamics in Europe.

Mikroekonometria. Modele i metody analizy danych indywidualnych (2012) ed. M. Gruszczyński. Expanded second edition. Warszawa: Wolters Kluwer Polska.

Mynarska, M. (2011) „Kiedy mieć dziecko? Jakościowe badanie procesu odraczania decyzji o rodzicielstwie" [When to have a child? A qualitative study of postponement of childbearing]. Psychologia Spoteczna 6(3): 226-40, http://www.spoleczna. psychologia.pl/pliki/2011_3/Mynarska_PS_3_2011.pdf.

Mynarska, M. and Styrc, M. (2014) „Preferencje i ograniczenia. Czynniki determinujące intencje posiadania pierwszego i drugiego dziecka" in A. Matysiak (ed.) Nowe wzorce formowania i rozwoju rodziny $w$ Polsce. Przyczyny oraz wplyw na zadowolenie z życia. Warszawa: Wydawnictwo Naukowe Scholar, pp. 54-76.

Nowe wzorce formowania i rozwoju rodziny $w$ Polsce. Przyczyny oraz wplyw na zadowolenie $z \dot{z y}$ cia (2014) ed. A. Matysiak. Warszawa: Wydawnictwo Naukowe Scholar.

Osiewalska, B. (2015) “Couples' Socioeconomic Resources and Completed Fertility in Poland". Studia Demograficzne 1 (167): 31-60.

Santarelli, E. (2011) "Economic Resources and the First Child in Italy: A Focus on Income and Job Stability". Demographic Research 25(9): 311-36, https://www. demographic-research.org/volumes/vol25/9/25-9.pdf.

Sobotka, T. (2008) "Overview Chapter 6: The Diverse Faces of the Second Demographic Transition in Europe". Demographic Research 19(8): 171-224, https://www. demographic-research.org/volumes/vol19/8/19-8.pdf. 
Soja, E. (2005) Hipoteza Easterlina w świetle zachowań prokreacyjnych generacji urodzonych w latach 1942-1966 w Polsce. Warszawa: Polskie Towarzystwo Ekonomiczne.

Spéder, Z. and Kapitány, B. (2009) Ideational Actors and Parenthood. A Gender- and Parity Specific Analysis in a Post-communist Society. Working Papers on Population 9. Budapest: Family and Welfare, Demographic Institute Hungarian Statistical Office.

Strukturalne $i$ kulturowe uwarunkowania aktywności zawodowej kobiet w Polsce (2009) ed. I. Kotowska. Warszawa: Wydawnictwo Naukowe Scholar.

Van de Kaa, D. J. (1987) “Europe's Second Demographic Transition”. Population Bulletin $42(1): 3-24$.

Van de Kaa, D. J. (1997) “Options and Sequences: Europe's Demographic Patterns”. Journal of the Australian Population Association 14 (1): 1-30.

Van de Kaa, D. J. (1999) "Europe and Its Population: The Long View" in D. J. Van de Kaa, H. Leridon, G. Gesano, M. Okólski (eds) European Populations: Unity in Diversity. Dordrecht: Kluwer Academic Publishers, pp. 1-49.

Vignoli, D., Drefahl, S. and De Santis, G. (2012) "Whose Job Instability Affects the Likelihood of Becoming a Parent in Italy? A Tale of Two Partners". Demographic Research 26 (2): 41-62, https://www.demographic-research.org/volumes/vol26/2/26-2.pdf.

\section{Abstract}

\section{Aktywność zawodowa a zachowania prokreacyjne w Polsce}

Polska jest krajem o jednej z najniższych dzietności w Europie. Wielu badaczy podjęło próbę wyjaśnienia przyczyn tej sytuacji. W literaturze przedmiotu za jedną z determinant niskiej płodności uznaje się sytuację panującą na rynku pracy - trudności w znalezieniu pracy, niepewność zatrudnienia, wysokie oczekiwania pracodawców wobec pracowników. W związku z tym młodzi ludzie mogą odkładać decyzje o rodzicielstwie na rzecz zdobycia lepszego wykształcenia, znalezienia zatrudnienia i ustabilizowania swojej pozycji na rynku pracy. Badania wpływu aktywności zawodowej na zachowania prokreacyjne dają niejednoznaczne rezultaty w zależności od kraju. Zróżnicowanie związane jest z sytuacją na rynku pracy (poziom zatrudnienia, wysokość płac), wsparciem instytucjonalnym oraz podziałem ról w rodzinie. W krajach o wysokich płacach bezrobocie jednego z rodziców nie musi ograniczać płodności (np. Dania). W krajach o relatywnie niskich płacach wpływ bezrobocia może przyczyniać do odraczania urodzeń (np. Hiszpania). Celem pracy jest zbadanie, jak w przypadku Polski aktywność zawodowa obojga partnerów wpływa na szanse posiadania pierwszego dziecka. W analizie uwzględniono cechy społeczno-ekonomiczne par takie jak miejsce zamieszkania, rodzaj związku, rodzaj gospodarstwa domowego, wiek kobiety, poziom wykształcenia partnerów oraz ich religijność. Weryfikacji poddano następujące hipotezy: (1) Zatrudnienie obojga partnerów zwiększa szanse na posiadanie pierwszego dziecka; (2) Bezrobocie jednego z partnerów zmniejsza szanse urodzenia pierwszego dziecka. Do weryfikacji tych hipotez wykorzystano model logitowy z efektami losowymi. Dane dla populacji polskiej pochodzą z Diagnozy Społecznej 2003-2013.

Słowa kluczowe: płodność, zachowania prokreacyjne, aktywność zawodowa, modele danych panelowych, modele logitowe z efektami losowymi. 